\title{
FENOMENA KEKERASAN: PERSPEKTIF HAM dan AL-QURAN
}

\author{
Maskur \\ Sekolah Tinggi Ilmu Agama Wali Sembilan Semarang \\ Email: curma.gund@gmail.com
}

\begin{abstract}
Abstrak
Kasus kekerasan umum terjadi di masyarakat maupun di instansi pendidikan. Berdasarkan data dari tahun ke tahun, kasus kekerasan bukannya semakin menurun secara kuantitas, tetapi selalu mengalami kenaikan yang cukup signifikan. Kajian ini bermaksud untuk melihat fenomena kasus kekerasan yang terjadi, terutama di instansi sekolah berdasarkan kajian dari nilai-nilai kemanusiaan dalam Islam. Sekolah seharusnya menjadi lembaga penting yang dapat menjadi tempat untuk mampu menanamkan nilai-nilai agama yang dapat dijadikan pijakan bagi siswa dalam bertindak dan bertutur kata. Berdasarkan kajian nilai-nilai menurut agama Islam, kekerasan jelas bukanlah perbuatan yang dianjurkan untuk dilakukan. Allah SWT memerintahkan kepada kita untuk selalu menjunjung tinggi qimah insaniyyah atau nilai-nilai kemanusiaan dalam setiap interaksi kita dengan manusia lain. Dengan demikian setiap manusia diperintahkan untuk berbuat baik terhadap sesama manusia tanpa membedakan agama, suku bangsa, ras, warna kulit maupun derajat kepangkatan seseorang.
\end{abstract}

Kata Kunci: Kekerasan, nilai kemanusiaan

\begin{abstract}
Violence case is common occur in society and in educational institutions. Based on data from year to year, violence case instead of diminishing in quantity, but always increasing significantly. The aim of this study is intends to look at the phenomenon of violence case, especially in school institution. Based on the study of human values in Islam, schools should become an important institution which can be place religious values that can be used as a reference for students in acting and spoken word. Based on the study of Islamic value, violence clearly not recommended to do. Allah commands us to always uphold qimah insaniyyah or human values in all of our interactions with other human beings. Thus every human being commanded to do good to fellow human beings without distinction of religion, ethnic, tribe, skin color or degree of a person's rank.
\end{abstract}

Keywords: violence, value, humanity 


\section{A. Pendahuluan}

Kasus kekerasan dalam dunia pendidikan memang bukan hal yang baru, akan tetapi melihat beberapa kasus kekerasan yang terjadi dalam dunia pendidikan mengalami peningkatan membuat permasalahan ini menjadi permasalahan yang perlu untuk segera ditangani dengan tepat, hal ini tentunya demi masa depan bangsa dan negara. Kekerasan ini merupakan hal yang harus diatasi karena angka kekerasan yang terjadi secara umum maupun secara khusus terjadi di lingkungan sekolah jumlahnya dari tahun ke tahun mengalami peningkatan. Berdasarkan data dari KPAI tahun 2014 mencatat 369 pengaduan terkait masalah bullying (kekerasan). Jumlah itu sekitar 25\% dari total pengaduan di bidang pendidikan sebanyak 1.480 kasus. Bullying yang disebut KPAI sebagai bentuk kekerasan di sekolah, termasuk tawuran pelajar, pemukulan dan pengeroyokan, mengeluarkan kata-kata kasar maupun kekerasan seksual yang terjadi.

Kurun waktu tiga bulan pertama di tahun 2014, KPAI menerima 252 laporan kekerasan pada anak. Adapun laporan kekerasan pada anak yang masuk ke Komnas PA didominasi kejahatan seksual terhadap perempuan maupun anak-anak dari 2010 hingga 2014 mengalami peningkatan yang mencengangkan yakni mencapai berkisar 42-62 persen. ${ }^{1}$

Melihat beberapa kasus kekerasan di lingkungan instansi pendidikan tentunya perlu upaya untuk melihat kasus kekerasan tersebut berdasarkan kajian nilai-nilai kemanusiaan berdasarkan kajian HAM maupun berdasarkan perspektif nilai-nilai kemanusiaan menurut agama Islam sebagai upaya untuk melihat beberapa hal yang terkait

\footnotetext{
${ }^{1} \mathrm{Http} / / /$ nasional.kompas.com/read/2014/05/07/0527140/Indonesia.Darurat.Kekerasan.pa da.Anak, diakses pada 26 Mei 2016
} 
dengan kekerasan dan langkah apa yang dapat dilakukan untuk mnegatasi kasus kekerasan yang terjadi dalam dunia pendidikan.

\section{B. Pembahasan}

\section{a. Kekerasan Sebagai Bentuk Pelanggaran HAM}

Secara etimologis, kekerasan merupakan terjemahan dari kata violence mempunyai arti kekuasaan atau berkuasa. kata violence, berasal dari bahasa Latin yaitu violentia yang berarti force (kekerasan). Secara terminologi, kekerasan (violence) didefinisikan sebagai perilaku pihak yang terlibat konflik yang bisa melukai lawan konflik untuk memenangkan konflik.

Kekerasan merupakan perbuatan seseorang atau kelompok orang yang menyebabkan cedera atau matinya orang lain atau menyebabkan kerusakan fisik atau barang orang lain, bisa juga suatu perbuatan yang disertai paksaan ${ }^{2}$. Sedangkan yang dimaksud dengan penganiayaan adalah perlakuan yang sewenang-wenang (penyiksaan, penindasan, dan sebagainya).

Kekerasan juga dapat diartikan sebagai tindakan pelanggaran (penyiksaan, pemukulan, pemerkosaan, dan lain-lain) yang menyebabkan atau dimaksudkan untuk menyebabkan penderitaan atau menyakiti orang lain. ${ }^{3}$ Soerjono Soekanto menyatakan bahwa kekerasan (violence) adalah penggunaan kekuatan fisik secara paksa terhadap orang atau benda. Adapun kekerasan sosial adalah kekerasan yang dilakukan terhadap orang dan barang karena orang dan barang tersebut termasuk dalam kategori sosial tertentu.

\footnotetext{
${ }^{2}$ Psikolog Malang, 13 Maret 2013, Memahami kekerasan: Definisi Kekerasan, www.psikologmalang.com, 16 Agustus 2016.

3/asiaaudiovisualra09gunawanwibisono.wordpress.com/2009/07/05/pengertian kekerasan, 12 Januari 2016.
} 
Colombijn menyatakan bahwa kekerasan adalah perilaku yang melibatkan kekuatan fisik dan dimaksudkan untuk menyakiti, merusak, atau melenyapkan seseorang atau sesuatu.

Stuart dan Sundeen menyatakan bahwa perilaku kekerasan atau tindak kekerasan merupakan ungkapan perasaan marah dan permusuhan yang mengakibatkan hilangnya kontrol diri di mana individu bisa berperilaku menyerang atau melakuakan suatu tindakan yang dapat membahayakan diri sendiri, orang lain, dan lingkungan.

Berdasarkan pengertian kekerasan yang dikemukakan oleh para ahli tersebut, maka dapat disimpulkan bahwa kekerasan merupakan yang dilakukan oleh seseorang maupun sekelompok orang yang untuk menyakiti fisik maupun psikis orang lain dengan memukul, menendang, mengumpat maupun melakukan tindakan yang tidak menyenangkan bagi seseorang maupun sekelompok orang.

Kekerasan atau sering dikenal dengan istilah bullying adalah perilaku kekerasan yang dilakukan seseorang atau kelompok yang memiliki kekuatan atau kekuasaan untuk menyakiti orang lain secara fisik maupun psikis melalui tindakan atau ucapan sehingga korban merasa tertekan, trauma, dan tak berdaya. Bullying yang terjadi di sekolah disebut School Bullying. ${ }^{4}$ School bullying termasuk dalam tindakan kekerasan yang merugikan orang lain, dalam hal ini dilakukan oleh siswa yang satu terhadap siswa yang lainnya. Disebut kekerasan karena tindakan yang dilakukan untuk menyakiti orang lain, atau bisa juga dengan tujuan tertentu, misalnya mencari perhatian, menginginkan kekuasaan di sekolah, ingin dibilang jagoan, pamer atau menunjukkan kekayaan seperti motor baru. Dengan demikian tindakan bullying ini dapat dilakukan oleh siswa maupun sekelompok siswa terhadap siswa

4 Ponny Retno Astuti, 2008, Meredam Bullying: 3 Cara Efektif Mengatasi K.P.A, Jakarta: PT Grasindo, hlm. 53. 
yang lainnya terutama ditujukan untuk mencari perhatian lebih dari orang-orang di sekeliling mereka.

Lebih khusus lagi Riauskina mengelompokkan perilaku bullying ke dalam 5 (lima) kategori:

a. kontak fisik langsung, seperti: memukul, menendang, memeras.

b. kontak verbal langsung, seperti: mengancam, merendahkan, memaki, memberi panggilan jelek, mempermalukan, menyebarkan gosip.

c. perilaku non-verbal langsung, seperti: bermuka sinis, menampilkan ekspresi muka yang merendahkan, biasanya disertai kekerasan fisik.

d. perilaku non-verbal tidak langsung, seperti: mengucilkan orang, memanipulasi keterangan, mengirim surat kaleng.

e. pelecehan seksual, seperti: kadang dikategorikan agresi fisik/verbal, seperti: mempertontonkan kemaluan kepada orang lain.

Bentuk-bentuk kekerasan tersebut tentunya akan memiliki dampak yang luar biasa bagi orang lain, khususnya bagi siswa yang mengalami bentuk kekerasan tersebut. Dengan demikian perlu adanya suatu tindakan yang tepat untuk mengatasi bentuk-bentuk kekerasan yang terjadi di lingkungan pendidikan. Hal ini tentunya berkaitan dengan pembentukan karakter anak-anak sebagai generasi penerus bangsa, bila masalah kekerasan dalam dunia pendidikan tidak diatasi dengan tepat, tentunya akan bermasalah bagi kelangsungan bangsa dan negara.

Kekerasan merupakan bentuk pelanggaran terhadap HAM, karena kekerasan menyalahi kodrat manusia sebagai ciptaan Tuhan YME. Hak Asasi Manusia adalah seperangkat hak yang melekat pada hakikat dan keberadaan manusia sebagai makhluk Tuhan Yang Maha 
Esa dan merupakan anugerah-Nya yang wajib dihormati, dijunjung tinggi dan dilindungi oleh negara, hukum dan pemerintah, dan setiap orang demi kehormatan serta perlindungan harkat dan martabat manusia. ${ }^{5}$ Menurut Dardji Dharmodihardjo, bahwa hak asasi manusia itu adalah hal pokok yang dibawa insan manusia sejak lahir secara otomatis sebagai pemberian dari Tuhan Yang Maha Esa. ${ }^{6}$ Adapun dalam pengertian HAM tersebut, pada dasarnya dapat diketahui pengertian yang lebih mendalam dengan mengetahui hakikat HAM, yaitu sebagai berikut: ${ }^{7}$

a. HAM berasal atau bersumbar dari Tuhan Yang Maha Kuasa yang diberikan atau dimiliki seluruh umat manusia tanpa membedakan berdasarkan strata sosial apa pun juga. HAM merupakan suatu hak yang secara kodrati melekat pada setiap individu sebagai anugerah dari Tuhan Yang Maha Esa pada umat manusia yang berlaku secara universal;

b. HAM berlaku untuk semua orang tanpa memandang jenis kelamin, ras, agama, etnis, pandangan politik atau asal-usul sosial dan bangsa. Pengimplementasian hak asasi manusia berkembang seirama dengan perkembangan pikir, budaya, cita-cita manusia dan IPTEK.

${ }^{5}$ Komnas HAM, 18 Maret 2013, Undang-undang No.39 Tahun 1999 Tentang Hak Asasi Manusia, www.komnas ham.go.id, 15 April 2016.

${ }^{6}$ Bimbingan, Januari 2014, Pengertian Pelanggaran HAM Menurut Ahli, www.bimbingan.org, 15 April 2016.

${ }^{7}$ Mansour Fakih dkk, 2003, Menegakkan Keadilan dan Kemanusiaan: Pegangan Untuk Membangun Gerakan HAM, Yogyakarta: Insist Press, hlm 132. 
c. HAM tidak dapat dilanggar, dalam artian tidak seorangpun termasuk negara mempunyai hak untuk membatasi atau melanggar hak asasi orang lain. Keberadaan HAM tetap melekat pada setiap orang sepanjang hidupnya tanpa dapat diambil atau dicabut, kecuali ada pelanggaran atas aturan hukum yang berlaku lewat keputusan peradilan yang senantiasa menjunjung tinggi terhadap perlindungan HAM.

d. keberadaan negara, antara lain untuk menghormati dan mempertahankan HAM sesuai dengan kesepakatan bersama demi pengembangan martabat kemanusiaan. Kesadaran memiliki dan melaksanakan hak asasi harus dikaitkan pula dengan kewajiban asasi dan tanggungjawab asasi.

Berdasarkan hakikat HAM tersebut, dapat diketahui bahwa HAM merupakan hak dasar manusia yang melekat pada diri setiap manusia, dan keberadaannya tentunya tidak dapat diganggu oleh orang lain. Dengan adanya HAM tersebut, keberadaan seseorang tentunya harus saling menghargai antara orang yang satu dengan orang yang lainnya dalam kehidupan bermasyarakat. Hal tersebut tentunya berkaitan dengan terwujudnya kehidupan yang harmonis dalam kehidupan bermasyarakat.

\section{b. Kekerasan Berdasarkan Nilai-Nilai Kemanusiaan Menurut Islam}

Kasus kekerasan merupakan tindakan yang tidak dibenarkan dalam agama apapun, termasuk agama Islam juga memiliki perspektif tersendiri dalam melihat kasus kekerasan. Islam merupakan salah satu agama yang mengecam bentuk kekerasan dalam hal apapun dan dalam bentuk apapun. Islam merupakan agama yang mengajarkan kepada umatnya untuk hidup rukun dan damai jauh dari tindakan kekerasan. 
Al-Qur'an telah memberikan pengajaran kepada manusia untuk memperhatikan nilai-nilai kemanusiaan dan menghormati manusia yang lainnya. Hal tersebut tentunya harus dijadikan sebagai patokan dalam mengatur kehidupan bermasyarakat, hal tersebut seperti yang tertulis di dalam Surat Al-Ma'idah ayat 8, yaitu:

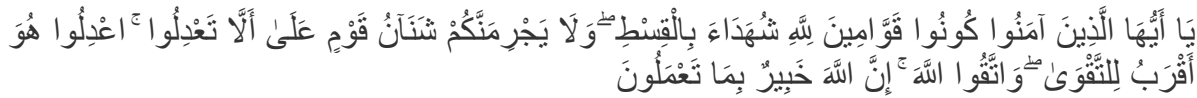

"Wahai orang-orang yang beriman, jadilah kamu sebagai penegak keadilan karena Allah menjadi saksi dengan adil. Dan janganlah kebencianmu terhadap suatu kaum, mendorong kamu untuk berlaku tidak adil. Karena adil itu lebih dekat dengan takwa. Dan bertakwalah kepada Allah sungguh Allah Mahateliti apa yang kamu kerjakan"8.

Allah SWT memerintahkan kepada kita untuk selalu menjunjung tinggi qimah insaniyyah atau nilai-nilai kemanusiaan dalam setiap interaksi kita dengan manusia lain. Setiap Muslim diperintahkan berbuat baik kepada manusia lain dan membantu manusia lain yang mengalami musibah, tanpa membedakan agama, suku bangsa, warna kulit atau derajat pangkat.

Hal tersebut sejalan dengan apa yang disampaikan oleh Satjipto Rahardjo bahwa "paradigma penegakan hukum semestinya lebih mengutamakan sisi kemanusiaan (keadilan) dibandingkan penerapan pasal peraturan (kepastian hukum). Penegak hukum tidak cukup hanya mengetahui kata dalam peraturan, tetapi harus mencari makna di balik kata itu." Sebagaimana firman Allah S.W.T. dalam Al-Quran Surat AnNisa' Ayat 58:

$$
\text { وَإِذَا حَكَنْنُم بَيْنَ النَّاسِ أَنْ تَحْكُمُو ا بِالْعَدْلِ إِنَّ اللَّهَ نِعِمَّا يَعِظُكُمْ بِه }
$$

8 Yayasan Penyelenggara Penterjemah Al-Qur'an, Al-Qur'an dan Terjemahannya, Bandung: Sinar Baru Algensindo, 2010, hlm. 210. 
Artinya: "Dan (menyuruh kamu) apabila menetapkan hukum di antara manusia, supaya kamu menetapkan dengan adil” (Q.S. An-Nisa': 58). Dan firman Allah S.W.T dalam Al-Quran Surat An-Nisa' Ayat 135:

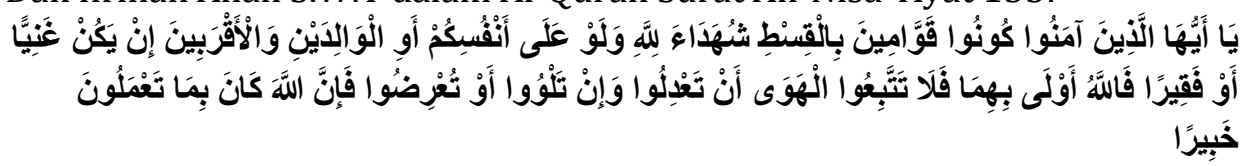

Artinya: "Wahai orang-orang yang beriman! Jadilah kamu penegak keadilan, menjadi saksi karena Allah, walaupun terhadap dirimu sendiri atau terhadap ibu bapak dan kaum kerabatmu. Jika dia (yang terdakwa) kaya ataupun miskin, maka Allah lebih tahu kemaslahatan (kebaikannya). Maka janganlah kamu mengikuti hawa nafsu karena ingin menyimpang dari kebenaran. Dan jika kamu memutarbalikkan (kata-kata) atau enggan menjadi saksi, maka ketahuilah Allah Maha teliti terhadap segala apa yang kamu kerjakan."(Q.S. An-Nisaa':135)."

Satjipto Rahardjo juga mengungkapkan bahwa penegakan hukum sebagai suatu permasalahan umum sedikitnya menampilkan dua aspek, yaitu sebagai usaha untuk mengekpresikan citra moral yang terkandung di dalam hukum dan sebagai suatu usaha manusia yang dilakukan dengan penuh kesengajaan. Bahwa hukum itu diam, dan hanya melalui penegakannya oleh aparat penegak hukum saja maka citra moralnya dapat diekspresikan. Atau hukum itu memuat janji dan melalui aparat penegak hukum janji-janji itu dapat diwujudkan dalam kenyataan.

Seperti yang tertulis pada Al-Qur'an di dalam surat Al Baqarah ayat 190: “Dan perangilah di jalan Allah orang-orang yang memerangi kamu, tetapi jangan melampaui batas. Sungguh Allah tidak menyukai orang-orang yang melampaui batas". Dari cuplikan ayat Al-Baqarah di atas bahwa Allah mewajibkan kita untuk membela diri apabila ada pihak lain yang mencoba

${ }^{9}$ Keadaan dan Permasalahan Dalam Penegakan Hukum Dewasa Ini. Kertas Kerja Dalam Simposium Masalah Penegakan Hukum, Badan Bina Cipta: Pembinaan Hukum Nasional, 1990, hlm.25 
memerangi/melakukan perbuatan yang mengancam kita akan tetapi kita tidak diperkenankan untuk memerangi melampaui batas, artinya Allah pun tidak menyukai perbuatan berlebihan walaupun beralasan demi membela hak-hak kita, contohnya adalah perbuatan balas dendam terhadap penganiaya, over protecting, dan lain-lain. Berdasarkan kajian hukum islam secara jelas dapat diketahui bahwa nilai keadilan merupakan dasar perlindungan terhadap HAM, di mana penerapan aturan hukum seharusnya sesuai dengan situasi dan kondisi riil yang terjadi.

Berdasarkan ketentuan hukum islam, perbuatan membela diri diperbolehkan, tetapi tidak membenarkan ketika harus membela diri dengan melakukan perbuatan yang melampaui batas yang ditentukan atau melakukan perbuatan yang melanggar HAM. Suatu aturan bukan hanya sebuah kata-kata melainkan peraturan tersebut harus dioperasionalkan sesuai dengan keadaan yang benar-benr terjadi, artinya suatu peraturan baru dapat bekerja bila telah ditegakkan oleh aparat penegak hukum. Dengan demikian keadilan dapat terwujud dapat ditegakkan manakala hukum telah dijalankan dengan menekankan nilai keadilan hukum sesuai dengan permasalahan yang telah terjadi.

Dengan demikian untuk menangani beberapa kasus kekerasan yang terjadi di instansi pendidikan adalah dengan melihat perbuatan tersebut dari segi HAM maupun dari nilai-nilai kemanusiaan menurut Islam. Apabila mendasarkan segala sesuatu berdasarkan perspektif agama, maka akan dapat diketahui bahwa perbuatan yang dilakukan merupakan perbuatan yang salah dan perbuatan yang melanggar hukum, baik hukum negara dan hukum agama. Dengan demikian perlu untuk menanamkan nilai kemanusiaan dan cinta kasih sayang terhadap sesama manusia terutama di kalangan para siswa.

Penanaman rasa penghormatan terhadap HAM dan penanaman rasa kemanusiaan terhadap sesama tentunya harus diupayakan melalui 
pendidikan agama yang kuat. Terutama harus ditanamkan rasa saling menghargai sesama manusia sebagai makhluk ciptaan Tuhan YME yang tentunya jauh dari unsur sempurna, dengan demikian bila terjadi benturan yang terjadi harus diselesaikan dengan jalan yang baik tanpa menggunakan unsur kekerasan. Bila siswa telah mengetahui peran dan kedudukannya sebagai makhluk ciptaan tuhan dan makhluk sosial yang dalam hidupnya membutuhkan peran orang lain, maka sedikit demi sedikit kasus kekerasan dapat ditanggulangi dengan sebagaimana mestinya.

\section{Simpulan}

Kekerasan atau sering dikenal dengan istilah bullying adalah perilaku kekerasan yang dilakukan seseorang atau kelompok yang memiliki kekuatan atau kekuasaan untuk menyakiti orang lain secara fisik maupun psikis melalui tindakan atau ucapan sehingga korban merasa tertekan, trauma, dan tak berdaya. Kekerasan berdasarkan perspektif HAM merupakan bentuk pelanggaran terhadap HAM, karena kekerasan menyalahi kodrat manusia sebagai ciptaan Tuhan YME. Hak Asasi Manusia adalah seperangkat hak yang melekat pada hakikat dan keberadaan manusia sebagai makhluk Tuhan Yang Maha Esa dan merupakan anugerahNya yang wajib dihormati, dijunjung tinggi dan dilindungi oleh negara, hukum dan pemerintah, dan setiap orang demi kehormatan serta perlindungan harkat dan martabat manusia.

Kekerasan dalam perspektif al-Qur'an telah memberikan pengajaran kepada manusia untuk memperhatikan nilai-nilai kemanusiaan dan menghormati manusia yang lainnya. Hal tersebut tentunya harus dijadikan sebagai patokan dalam mengatur kehidupan bermasyarakat. Allah SWT memerintahkan kepada kita untuk selalu menjunjung tinggi qimah insaniyyah atau nilai-nilai kemanusiaan dalam setiap interaksi kita dengan manusia lain. Setiap Muslim diperintahkan berbuat baik kepada manusia lain dan membantu manusia lain yang mengalami musibah, tanpa 
Maskur

membedakan agama, suku bangsa, warna kulit atau derajat pangkat. Dengan demikian perilaku kekerasan dalam bentuk apapun jelas menyalahi Hak Asasi Manusia dan agama yang senantiasa mengajarkan nilai-nilai kemanusiaan dan menghormati manusia yang lainnya. 


\section{DAFTAR PUSTAKA}

Agus Salim MS, Teori dan Paradigma Penelitian Sosial,Yogyakarta: Tiara Wacana, 2006

F. Magnis Suseno, Kuasa dan Moral, PT. Gramedia Pustaka Utama, Jakarta, 2001.

Komnas HAM, 18 Maret 2013, Undang-undang No.39 Tahun 1999 Tentang Hak Asasi Manusia, www.komnas ham.go.id, 15 April 2014.

Mansour Fakih dk, Menegakkan Keadilan dan Kemanusiaan:Pegangan Untuk Membangun Gerakan HAM, Yogyakarta:Insist Press, 2003

Ponny Retno Astuti, Meredam Bullying: 3 Cara Efektif Mengatasi K.P.A.Jakarta:PT. Grasindo, 2008.

Psikolog Malang, 13 Maret 2013, Memahami kekerasan: Definisi Kekerasan, www.psikologmalang.com, 16 Desember 2014.

Satjipto Rahardjo, Keadaan dan Permasalahan Dalam Penegakan Hukum Dewasa Ini. Kertas Kerja Dalam Simposium Masalah Penegakan Hukum, Badan Bina Cipta: Pembinaan Hukum Nasional, 1990

Yayasan Penyelenggara Penterjemah Al-Qur'an, Al-Qur'an dan Terjemahannya, Bandung: Sinar Baru Algensindo, 2010 